\title{
Practical Mysticism, Habermas, and Social Work Praxis
}

\begin{abstract}
Summary: Mysticism holds that there is an unseen non-empirical reality which is just as important in people's lives as concrete, observable reality and experience. Practical mysticism implies that this unseen reality results in concrete experience and a particular kind of knowing which is just as influential on people's actions and behaviour as observable reality. The authors draw a connection between practical mysticism and the increasing interest in themes relating to religion and spirituality in social work. These themes relate mainly to issues of meaning, motivation and intention in social work. Like all service professions, social work is undergoing re-evaluation away from merely pragmatic and instrumentalist conceptions of its mission to ones concerned with broader issues of meaning and purpose. In this context, issues of religious and spiritual motivation and intention become relevant.

Findings: We propose that 'practical mysticism', arguably revived in Habermasian critical theory, has particular relevance to debates relating to the role of religion and spirituality in social work education and practice. Importantly, practical mysticism has the effect of impelling a rethinking of the relationship between spirituality, religion and the applied values inherent in day-to-day social work practice We see the consideration of practical mysticism to be a fruitful way of embracing religious and spiritual
\end{abstract}


discourses relevant to social work, including their link with social work ethics and practice.

Applications: When combined with Habermasian critical and communicative action theories, a practical mystical approach to social work impels a practice (or praxis) with enhanced potential to motivate the actions of social workers themselves, including in their sensitivity to the religious and spiritual motivations and needs of their clients, and so their capacity to engage more effectively with these clients.

Key words: Practical mysticism, Habermas, religion, spirituality, social work values

\section{Introducing the Notion of Mysticism to Social Work}

Conceived in terms of Habermas's (1972, 1974, 1984, 1987) ways of knowing and communicative action theories, especially around the concept of his emancipatory knowing, the moral intention of the social worker becomes a pivotal part of social work praxis, such that practical judgment-knowing what to do in the moment-is where knowing and understanding become, at one and the same time, an epistemological and ethical engagement. Such phenomenological understanding is not new to social work but the idea that there is mysticism involved certainly is. This mysticism-or inner knowing - has been expressed in other ways by a line of thinkers who have sought to embrace and even manage subjectivity in social work (see, for example, England, 1986). It implies that there is an implicitness in knowing what to do in the moment borne of intuition and practical wisdom such that an effortlessness and seamlessness arises when social workers follow their heart, when they become virtuosos, thoroughly in tune with their clients (Gray, 2007). Authenticity is a word which springs to mind- 
being able to act in keeping with one's values and to do what seems to come naturally in the situation. There is no standing back and reflecting, or carving the encounter into analyzable bits and putting them back together again, but rather an ability to respond to the 'whole man (sic)’ (England, 1986).

Herein, social work becomes an art where the social worker starts with a full canvass and is able to read the dynamics of what is going on and what is demanded of her while, at the same time, not straying from her values. What the mystics learned about religion as being a lived phenomenon rather than a dogmatic set of context-free prescriptions, is what social work needs to regain. This is where spirituality seems to enter the picture for it appears to offer a way to regain the mystical aspects of what we do and simultaneously to ward off institutional tendencies towards callousness of managerial efficiency, of social work as a bureaucratic function rather than a value-based activity.

What we would argue is that there is an ineffable aspect to what social workers do-a part of helping and engaging with others that defies rational explanation, that just 'feels right' in the moment and that 'hits the mark' for no reason beyond it 'being right'. Whether referred to as 'subjective', 'spiritual', 'intuitive' or 'mystical', it is ever present when we explain those features that are most easily able to be articulated. Social workers are increasingly sharing this perspective in spirituality discourses which have become catchments for social work's disenchantments.

\section{Spirituality and Social Work's Disenchantments}


At the heart of social work's spirituality discourse lies a personal search for meaning and purpose, for meaningful relationships with others, the encompassing globe and, one might even say, the ontological ground of existence. It has become a kind of secular religion in a religio-phobic professional culture which allows for 'religion without religion', that is, for identification with religious culture while reducing the importance of 'personal religious faith' (Holloway, 2006, p. 2). Instead, it encourages a postmodern relativism which allows for a wide range of theistic stances. It amounts to a tacit acknowledgment that, in spite of the epoch of secularization that has dominated in the recent past, there is still much emphasis on the 'Divine' within each one of us, on the 'sacred', and on spirituality as a means to assuage our feelings of alienation and separateness. There is agreement that we are all spiritual beings by nature but we do not necessarily agree on the nature of our spirituality.

As a symptom of this age of political correctness, the spirituality discourse emphasizes the inclusion of diverse and often conflicting assumptions about values, approaches, and practices relating to the 'sacred'. It reinforces social work's core values of respect, openness, non-judgementalism, and social justice. Graham (2006) sees spirituality as part of a movement to 'indigenize' and localize social work practice in diverse communities around the world. It thus attempts to transcend boundaries whether cultural, religious, gender, age, ethnic, and so on, and to honour the diversity of local beliefs and spiritual traditions. It encourages local helping and healing practices while, at the same time, encouraging inter-cultural dialogue and a global perspective. It promotes multiculturalism or 'religious and cultural pluralism' (Holloway, 2006, p. 2) and the idea of 'cultural competence' in which social workers can easily slip between 
cultures by learning about and working with diverse cultures. Of importance, then is 'an understanding and appreciation of the impact of faith and belief” (Gilligan and Furness, 2005, p. 1). At the same time, it must address and redress Holloway's (2006) finding that culturally sensitive practice too often tends ‘to limit itself to respect for another's religious customs and practices' (p. 8) and does not necessarily result in 'antioppressive practice’ wherein discriminatory beliefs and practices are overtly challenged.

In addressing the above concern, Patel (in Holloway, 2006) believes that a focus on religion does have potential to lead to ‘a deeper appreciation of anti-racist practice’ (p. 8). On the other hand, while seeing Patel's attempt to raise the issue of religion within an anti-racist framework as laudable, Henery (2003) believes she further entrenches common stereotypes of ethnic minorities as 'religious first and spiritual second' (p. 1010). Ethnic minorities are cast as ‘the custodians of religion’ (Henery, 2003, p. 1111) while everyone else, freed from the constraints of mainstream Christianity, pursues 'the individual consumer-orientated lifestyle option of spirituality' and, in this way, removes religion 'from the core business of social work' (Holloway, 2006, p. 11; see also Gray, 2006).

While it might make way for 'the traditional, the local, the colourful and the exotic' (Henery, 2003, p. 1111), spirituality in social work is overwhelmingly individualistic (Gray, 2006). It offers a smorgasbord from which to pick and choose which includes belief in angels and demons, extra-sensory perception, transpersonal psychology, Eastern mysticism, Wicca, chi, kabbalah, and kundalini. All offer a way to discern meaning via inter alia expanding awareness, transcending ego boundaries, and attaining 
cosmic consciousness, connecting with nature, and, above all, gaining enlightenment. It offers what Holloway (2006) refers to as 'homeless humanism' or the tendency to hold 'humanistic beliefs not related to any religious creed' (p. 2). It heralds a return to the essentialist search for our 'true nature' or the awakening of the 'true self' and becoming who we 'truly are' through self-realization and self-actualization. Important in this process is the spiritual guide, the counsellor, shaman, guru, and so on.

In short, says Henery (2003), the spirituality movement has taken religion to the marketplace such that we can have small palatable doses of it in secular guise. Unlike religion, which is seen as prescriptive and conformist, spirituality prides itself in breaking and transcending boundaries, in transforming taken-for-granted assumptions, in overcoming absolutism and relativism. It sees itself as open-minded and mindful, flexible and non-judgemental. In our consumerist, risk-generating culture (Beck, 1992; Giddens, 1991), maximizing personal choice, searching for personal enlightenment and focusing on the 'inner' life is the reinvigorated psychology which safeguards us against the 'thought police' who would tell us what to believe.

The spirituality literature is overtly critical of all the above. As Henery (2003) sceptically notes, it 'is commonplace in the spirituality literature to criticize modern culture-for its materialism, scientism and consumerism' (p. 1110) yet to deny the fundamental affinity between the spirituality project and the very 'isms' from which it seeks to distance itself. Ironically, 'despite its claim to the contrary, the literature on spirituality seems to complement rather than counteract dominant social arrangements' (Henery, 2003, p. 1112). One way in which it does this is through its focus on the 
'self'—on people's need for 'self-care', 'personal healing', 'wholeness', and 'connectedness to others' - to overcome the worst effects of modernity. It focuses on our need to 're-centre' ourselves through 'embracing the sacred' and the 'resilience of the human spirit', the 'inner wellspring of energy on which we draw' (Collins and Laughlin, 2006). To do this, as outlined above, it supports a consumerist culture of expertise, self-help and self-development. Self-care is big money!

These then are the major differences between religion and spirituality as they are being written about in the social work literature and talked about at social work conferences, although it must be acknowledged that the spirituality movement still remains marginal in social work in comparison with the long-established clinical—mental health lobbyin the US, and the growing evidence-led practice movement in the UK, Europe, Scandinavia, Australia, and North America. Some would say 'the bad guys are winning'. The spirituality movement is strongest in North America, catching on in Australia and a minor player in the UK (Holloway, 2006).

In a culture where morality seems to have taken a backseat, spirituality introduces a strange mix of depth and transpersonal psychology, personality theory, art, creativity, emotions, meaning, and what is merely deemed 'good for all of us'. In fact, it is often difficult to discern where spirituality comes into the equation for much of the theory is psychologistic. New Age spirituality combines depth psychology, Eastern mysticism and Indigenous perspectives into a mixed bag of self-help, self-care, and selfdevelopment techniques and approaches. Overall, spirituality in social work is an individual matter; it is presented as being highly personal (Gray, 2006). In many ways, 
this discourse avoids the issue of social work's authentic and inextricable religious roots.

\section{Social Work’s Authentic Religious Roots}

Bent on professionalisation, social work has worked hard to rid itself of its authentic religious roots and this trend is seen, by some, to continue in the strong interest in spirituality in social work which has been attributed to people's quest for meaning and purpose in their lives as well as to their attempts to transcend the limitations of traditional religion. However, religion and spirituality are intertwining concepts and other forces are afoot in bringing them back onto the social work agenda, not least the growing multiculturalism (cultural pluralism) and diversity of service users (Gray, Coates and Hetherington, 2007). Oriented as they are towards religious (and cultural) pluralism, social work's strong values of acceptance of difference encourage social work practitioners to engage with the full spectrum of religious affiliations without favouring a particular religious tradition. However, acceptance of diversity and engagement with pluralism are not the same thing: One can observe and celebrate diversity without being affected by it, but pluralism involves participation and being part of the development of an inclusive civil society (Eck, 1993). Religious pluralism involves active engagement in the way of practical mysticism; it involves living and acting in keeping with one's values.

Generally, whether experienced within or outside of a religious tradition, spirituality has to do with inner experiences, with a connection to one's inner world. At times, it is hard 
to distinguish spirituality from psychology yet, at other times, stories of spiritual healing would be hard to explain within any Western psychological theory of change. At times, spirituality might be seen as a new genre of psychology, a revivified Jungianism and a mixture of mysticisms of all types, Buddhist, Jewish, New Age, Indigenous, and so on, yet, at other times, it is seen as mystical and ineffable. However, there is some agreement that spirituality has to do with holism - the whole person - in interaction with the social and natural environment and, beyond this, it concerns people's connectedness and oneness with the larger universe. Mostly, it is non-rational, intuitive and subjective, and perhaps even postmodern, in the sense that it has superseded more traditional and structural forms of religion. Therefore, there is a paradox in trying to take this deeply personal and mystical experience and convert it into technical assessment intervention frameworks and measures which require conceptual clarity and (artificial) definitions of (differences between) religion and spirituality for the sake of measurement. Princeton sociologist, Robert Wuthnow, in his considerable research on religion in the USA, notes that most people equate spirituality to their (personal) relationship with God and find ways to pursue it within their religious traditions. Sheridan (2003) cites statistics in 2000 showing that more than three quarters of the US population are Christian, with 1.3\% Jewish, 0.5\% Islamic, 0.5\% Buddhist and 0.4\% Hindu. This means that the diverse forms of spirituality influencing social work discourse on spirituality - most of which comes from social work academics writing in the USA - sit on the extreme fringe of US society where organized religion continues to be important to the vast majority of people's spirituality. Wuthnow's (2002) research shows that people interested in the arts and in spirituality tend either already to be involved or have become involved again in religious organizations, while people who 
are religiously affiliated generally tend to be more community oriented than those who are not. In short, he says, when it comes to religion, the US population can be divided into four categories:

Roughly the top quarter of the public ... is very committed. They take their spiritual life very seriously, pray routinely, are active in their religious organizations, and so forth. The second quarter, and even the third quarter -- the middle 50 percent of the public -- is sort of religious. They're involved. They go once in a while. They pray once in a while. They believe some of the right things. They may even think it's pretty important to them, but they don't make a big commitment to it. And the remaining quarter say they're pretty much just indifferent to religion. My guess is that may not be terribly different than the way it's been for a long time (p. 4).

There is far more to be gained from the serious study of religion in social work and from a close and deep reading of the practical mystics for whom religion was eminently practical and faith a lived reality. Social work is suffering too much from a surface reading of religion and going too far in embracing every new fad on the market, unwittingly fuelling the very consumerist culture which it ostensibly abhors. Wuthnow (2002) puts it thus:

Organized religion lost its monopoly over spirituality. If you go back, say, to the 1950s, there weren't many places to shop for spirituality, unless you went to an organized church or synagogue. Nowadays, you can go to the local bookstore, or 
a retreat center or some kind of New Age center, or you can order up tapes or CDs, or go to a concert. In other words, other parts of the society got in the act and found that they could supply some of our spiritual views. You can look at people and almost make a judgment of how hard they work at their spirituality. Of course, this is bad theology, because it's all supposed to be grace. But some people think that, whatever their theology is, it really does require some commitment. And they actually spend considerable time every day praying or reading the Bible or being of service to other people or preparing lessons to teach at their church. That does take a lot of time and commitment, and that kind of commitment runs against the grain of our society that tells us we ought to be able to get fast food, instant meals, instant gratification. The rest of what goes on in American spirituality is catering to that impulse to get things as quickly and easily as possible (p. 4).

It is our contention that a close study of Habermasian critical and communicative action theories, on the one hand, and, on the other hand, inherent links we believe we can demonstrate with the cut and thrust of practical mysticism as spelled out in mainstream religious cultures has potential to open up new lines of thought which can impact positively on social work’s identity and contemporary search for enhanced practice.

\section{Habermas and Religion}

Habermas once said (in Past as Future, 1994) that when one is swimming around in the sea of ideas, it is important to specify what discourse one is in for each discourse has its own rules. It is also important to discern the history of ideas informing the writer of the 
particular discourse in which one is situated. In Religion and Rationality (Habermas, 2002), it becomes clear that the ideas or thought of the Jewish philosophers of the Frankfurt School with which Habermas associated were extremely influential on his ideas about religion. Thus, for our purposes in this paper, when we are talking about practical mysticism, we are never far from the discourses of Western religion and spirituality.

Habermas (2002) claims that religious discourse clearly sets out to explain how and why we ought to follow God's word; herein, the existence of God, or whichever deity the particular religion is concerned with, is taken as a given. Theology is the discipline which studies the meaning and import of religious doctrines and attempts to give them a philosophical underpinning. Here, theology comes close to philosophy which concerns itself with trying to find rational justification for its ideas. Many religious philosophers have tried to provide rational explanations for God or the Absolute and metaphysics is the branch of philosophy essentially concerned with such matters. However, following Kant's critique of metaphysics, the absolute became 'unrepresentable' in philosophy (Mendietta, 2002, p. 7). Instead Kant privileged moral obligation rather than religious explanations as a way to pursue the 'good' in society. Habermas continues this tradition, seeking to find a way to express his ideas for a secular world. In this way, he makes his discourse ethics a means of engagement by which we reach a shared understanding about what is required for us to live harmoniously in a world with others. In his own words, '... discourse ethics attempts a translation of the categorical imperative into a language that also lets us do justice to another intuition - I mean the feeling of 'solidarity', the bond of a member of a community to her fellow members' (Habermas, 2002, p. 163): 
I would not object to the claim that my conception of language and of communicative action oriented toward mutual understanding nourishes itself from the legacy of Christianity ... Already the communicative-theoretical version of the concept of emancipation in Knowledge and Human Interests could be "unmasked" as the secularising translation of the divine promise of salvation (Habermas, 2002, p. 160).

Importantly, then, Habermas (2002) sees one of the main functions of traditional and metaphysical worldviews as being to integrate individuals into society by offering bridges between individual and group identity, while providing a cognitive handle on the natural world. 'Neither science nor art can inherit the mantle of religion; only a morality, set communicatively aflow and developed into discourse ethics, can replace the authority of the sacred' (p. 24). For Habermas, 'as long as religion can still say something that philosophy cannot, then philosophy, even in its postmetaphysical form, will not be able to replace or repress religion’ (p. 26, also p. 79). Philosophy cannot provide a substitute for the consolation offered by religion in helping people learn to cope and bear with hardship: 'Philosophy has never and can never be a source of existential consolation' (Habermas, 2002, p. 26). On the other hand, religion can address these matters. In referring to Scholem's work, however, Habermas (2002) says that '... the change that religion, in particular mysticism, has undergone through its transformation into political utopianism and religious nihilism, has been both unavoidable and unsatisfactory’ (p. 27 emphasis added): 
... paraphrasing Kant, by way of both Adorno and Bloch, in Habermas' view "religion without philosophy is speechless, philosophy without religion is contentless; both remain irreducible as long as we must face our anthropological vulnerability without consolation, without ultimate guarantees” (Mendietta, Introduction to Religion and Rationality, 2002, p. 28).

Importantly, Habermas (2002) acknowledges that '... everything to do with morality ultimately derives from theology' (p. 99) but ‘theology cannot provide a substitute for religion, for the latter's truth is nourished from the revealed Word, which from the beginning appears in religious not scholarly form' (p. 164). What then of the more explicit links to Aquinas which are central to our thesis about Habermas's practical mysticism? Habermas (2002) himself said, 'I am an admirer of Aquinas’ (p. 152).

\section{Habermas and Practical Mysticism?}

Consistent with the above, Habermas acknowledges mysticism when he cites Wittgenstein's assertion that 'There are indeed, things that cannot be put into words. They make themselves manifest. They are what is mystical' (2002, p. 46 emphasis added). But what is mysticism? The term 'mysticism' is often used to refer to beliefs which go beyond the purely exoteric practices of mainstream religions while still being related to or based in a mainstream religious doctrine, that is, the idea that knowledge can be gained by experience and, therefore, can be ascertained by anyone. Examples are Kabbalah in Judaism and Sufism in Islam. Esotericism, on the other hand, is usually associated with Eastern religion, for example, Buddhism's Vajrayana and various branches of Hinduism, all of which have broad 'all-paths' embracing philosophy with 
many mystical branches (http://en.wikipedia.org/wiki/Mysticism). As we have seen, by mysticism, we refer to a pathway by which to achieve a definite state of higher consciousness and to develop spiritual discernment which is highly personal and part of the 'inner life' of the individual. Rather than only implying one's psychological makeup, it recognises humans' spiritual being. In the notion of practical mysticism, we draw on a mystical tradition that spreads from Plotinus (2005) to al-Ghazzali (1991) and on to Cordovero (1974) and, for Christians resides most obviously in the Aristotelian-inspired thoughts of Aquinas about the highest knowing being indistinguishable from knowingin-action. For Aquinas (1936), synderesis was a God-given facility that impelled the most profound knowing, of God and oneself and, at the same time, required practical action that was consistent with this knowing. In other words, there can be no claims to mystical knowing without action that demonstrates its authenticity.

Elsewhere (cf. Lovat, 2006), a conceptual link between, on the one hand, Habermas's (1972, 1974, 1984, 1987) ways of knowing and communicative action theories and, on the other hand, the pragmatic and phenomenological thread implicit in the notion of practical mysticism, has been demonstrated. Habermas’s emancipatory knowing asserts that, when it comes to our emancipatory interests, 'it is all right to start with ourselves if we seek to understand the world, to change the world, or both' (Doughty, 2003, p. 4). This can only be reached through 'a higher stage of reflection, a consciousness of acting human beings moving forward in the direction of emancipation' (p. 8): 'Habermas attempts to provide us with the tools to "deconstruct" our own ideological limitations, to supply us with a practical guide to developing some ethical considerations about the matter of social change in general ...' (p. 9). He addresses 'concrete issues of social 
equity and justice by demonstrating the human interests that inhere in types of knowledge and modes of inquiry’ (p. 13).

Habermas's work is useful in the context of any discussion about mysticism because of its radical re-defining of the nature of knowing, a concept that lies at the heart of mysticism of all kinds but that has particular ramifications for practical mysticism. It is also useful in that it makes some of the thought of mysticism, and especially practical mysticism, available to an era that is not naturally disposed to such things. While Habermas has spent his career known chiefly as a neo-Marxist and probably atheist, in his later years his work has turned in obvious fashion to issues related more explicitly to theology, spirituality and the mystical thought that we would maintain was actually never far from his grasp (Habermas, 2002; Martin, 2005). According to Mendietta (in the Introduction to Religion and Rationality, 2002), 'Habermas has ... continued to maintain questions concerning religion close to the center of his thought' (p. 13) and the JudeaoChristian tradition forms the backdrop to Habermas's thought on religion as well as social work’s cherished values.

Habermas $(1972,1974)$ touches on recognizably mystical notions in challenging us to consider the different ways in which we claim to know. Knowing facts and figures is important, he says, as is the knowing of communication and meaning-making, but the knowing that most truly marks out human intellectual endeavour and has the capacity to transform self and community is critical or self-reflective knowing. Ultimately, this is a critique of all knowing that renders in a profound knowing of self and issues in praxis, in practical action for change. In a word, one cannot come to know in this profound 
sense, including knowing of self, without being changed. It is through the process of coming to know self, invariably entailing an agonizing struggle, that one gradually strips away the inherited knowledge, the familial and cultural baggage, and the ignorance that is so often the source of relational misunderstanding, bigotry, hatred, and violence. For Habermas, this latter was the supreme knowledge that marked a point of having arrived as a human being. One might caricature him as saying, 'There is no knowing without knowing the knower', and the knower is oneself. In a sense, the ultimate point of knowing is to be found in knowing oneself.

Praxis is the necessary concomitant action that results only from knowing self in this radical—and quite mystical—way. This is a practical action that makes a difference to whatever it is directed towards. Like the kabbalist Cordovero's (1974) mystical attributes, Habermas's practical action is beyond the action that is characteristic of knowing prior to the knowing of self. It is the action of radical, unselfish commitment to a cause, a community or an individual that brings a new force into being. In another place, Habermas $(1984,1987)$ develops his thoughts on praxis in eliciting the notion of communicative action. On the surface, the notion is of global communicative competence, however, at a deeper level there lies a thesis about effective practical action being the result of the most profound knowing, especially the knowing of self. In a word, the most effective artefacts of communicative action can only come from the wellspring enshrined in the notion of self-reflectivity, from one who knows who they are, values the integrity of being authentic and commits to the benevolent actions and positive relationships that bear the best fruits of human interactivity. Habermas has provided an updated and highly credible justification and elaboration of the practical 
mysticism that underpins notions of authentic religiousness in those traditions that have had most influence on the West and its institutions. As such, this is a practical mysticism that can lay claims to provide for a relevant spirituality for the institution of social work.

Clearly, Habermas recognizes that our interests guide our thoughts and emotions and provide direction for our concentration and what we need to know. Furthermore, it is clear that emancipating interest impels a knowing need that renders knowledge and practical action as identical. Putting together his acknowledgment of mysticism as an authentic knowing within religious contexts and his overarching concern that all supreme knowing be measured by the acid test that it leads to praxis, practical action for good, we believe we are on solid ground in inferring a conceptual link between Habermasian self-reflective knowing and practical mysticism. After all, whether one speaks of critical reflection or meditation, one is describing a process of heightening consciousness or awareness of one's own knowing. By the terms of both Habermas and practical mysticism, this knowing requires practical action in order to claim authenticity. For Habermas, this action will take the form of enhanced commitment to and effective engagement with the justice issues in one's society. In the classical terms of Jewish, Christian and Islamic practical mysticism, seen in the likes of Cordovero, Aquinas and al-Ghazzali, it will issue in enhanced kindness, generosity and love towards others such that the love of God can be enacted towards building up the 'People of God', that community that will testify to God's love by its own acts of love.

\section{Practical mysticism and social work}


When we talk about practical mysticism in relation to social work, we are engaged in social work discourse related to religion and spirituality. Writers in the area of spirituality in social work consistently emphasize the difference between religion and spirituality (Furman, Benson, Grimwood \& Canda, 2004; Gilligan \& Furness, 2005; Henery, 2003; Holloway, 2006; Sheridan, 2003). The way these differences are conceptualized reflects a 'deep-rooted, historical antipathy towards religion' among social workers in Western societies, where, as social work professionalized, it sought 'to distance itself from its Christian charitable foundations' (Holloway, 2006, p. 4). Thus as social work embraced professionalism it became increasingly secular in nature (Gray, 2006). Against this backdrop, it is not hard to see why, in the social work literature, 'spirituality is the favoured half of the (religion-spirituality) binary' (Henery, 2003, p. 1109). This seems to flow from a biased and narrow conception of religion in the social work literature.

Drawing on the notion of 'practical mysticism' identified above, and which, we believe, is entirely consistent with the notion of praxis in social work, we argue that social workers have been misled about the nature and function of religion in people's lives. As demonstrated above, we are aided in our quest by Habermasian critical theory which has important synergies with an understanding of religious knowing as impelling and demanding practical action for good. Unlike cum ci cum ca spirituality, it has a moral underpinning which grounds social work in the pursuit of core values, such as social justice and respect for others, over others, like professional domination and cultural homogenization. It is our opinion that now more than ever before social work has to grapple with the important role that religion plays in its history and contemporary 
practice. This is a valid observation, whether from the historical vantage-point that social work's primal values are inseparable from its Judeao-Christian tradition, or from the contemporary insight that, as social work grows in the newly professionalizing Eastern nations, it has to grapple with the commonalities and differences inherent in all religious traditions and in contexts where secularization has not held sway as it has in the West. Practical mysticism, we argue, offers common ground for bridging these cultural differences and, moreover, serves as a vehicle through which all mainstream religions pursue practical action for the common good.

\section{So What Place for Practical Mysticism?}

How then might the unity of religion and the diversity of spirituality be reconciled? We suggest that practical mysticism offers a more positive way of approaching religion as practical action for the good. Such an approach is compatible with social work's praxis in which reflexive, self-aware individuals live out their values and beliefs in their practice. Not all the parts of what we do are amenable to explanation and description. There is an implicitness, a 'knowing that what I did was right kind of feeling' that characterizes our work. Over the years, it has been expressed in various ways, as the subjective side of what we do, as practice wisdom, as the intuitive use of self, as art, and so on. We see spirituality as one attempt to affirm the subjective, ineffable parts of what we do and to rediscover meaning in our professional life but it is problematic and we need to take a far more critical look at spirituality in social work (Gray, 2006).

Perhaps more might be gained by a deeper study of religion as faith rather than prescription through the work of those who are trying to discern a common core of 
values, which diverse religions share, through the study of practical mysticism. If social work were to pay more attention to the theological and philosophical underpinnings of diverse religions, it might realise that its aversion to religion is misguided most importantly because it distances the profession from cultures and peoples for whom religion and life are inseparable.

There is a more fruitful way to embrace religious discourse and to link it with social work praxis than to associate religion with dogma and fundamentalism and spirituality with a search for personal meaning and purpose. At the heart of social work's aversion to religion lies its fear of absolutism and moralism, but religion need not be so. In fact, spirituality can just as easily be a haven for fixed thinking and dogmatic beliefs which is possibly why it has some links to social activism through environmentalism and so on. There is another route to be followed by a more close study of practical mysticism which leads to an understanding of common values across religions resulting in praxis, practical action for good.

\section{Conclusion}

In this paper, we have proposed that 'practical mysticism' is relevant to debates relating to the role of religion and spirituality in social work education and practice. Practical mysticism has the effect of impelling a rethinking of the relationship between spirituality, religion and the applied values inherent in day-to-day social work practice We see the consideration of practical mysticism to be a fruitful way of embracing religious and spiritual discourses relevant to social work, including their link with social work ethics and practice. When combined with Habermasian critical and 
communicative action theories, a practical mystical approach to social work impels a practice (or praxis) with enhanced potential to motivate the actions of social workers themselves, including in their sensitivity to the religious and spiritual motivations and needs of their clients, and so their capacity to engage more effectively with these clients in an increasingly pluralistic world.

\section{References}

al-Ghazzali, A. (1991) The Book of Religious Learnings. New Delhi: Islamic Book Services.

Aquinas, T. (1936) Summa Theologica. (tr. L. Shapcote) London: Burns \& Oates.

Aristotle, (1985) Nicomachean Ethics. (tr. T. Irwin) Indianapolis: Hackett.

Armstrong, A. tr. (1996) Plotinus, Ennead II. Loeb Classical Library. Cambridge, MA: Harvard University Press.

Augustine (1972) City of God. Harmondsworth, UK: Penguin.

Bauman, Z. (1997) Post-modernity and its Discontents. Cambridge: Polity Press.

Beck, U. (1992) Risk Society: Towards a New Modernity. London: Sage. 
Coates, J. (2003) Ecology and Social Work: Toward a New Paradigm. Halifax: Fernwood Press.

Collins, B. \& Laughlin, T. (2006) 'Embracing the Sacred in our Work', presentation at the First North American Conference on Spirituality and Social Work, Waterloo, Canada, 25-27 May 2006.

Cordovero, M. (1974) The Palm Tree of Deborah. (tr. L. Jacobs). New York: Hermon Press.

Derezotes, D. \& K. E. Evans (1995) 'Spirituality and Religiosity in Practice: In-depth Interviews of Social Work Practitioners', Social Thought 18(1): 39-56.

England, H. (1986) Social Work as Art: Making Sense for Good Practice. London: Allen \& Unwin.

Epstein, P. (1988) Kabbalah: The Way of the Jewish Mystic. Boston: Shambhala.

Furman, L. D., Benson, P. W., Grimwood, C. \& Canda, E. (2004) 'Religion and Spirituality in Social Work Education and Direct Practice at the Millennium: A Survey of UK Social Workers’, British Journal of Social Work 34: 767-792.

Giddens, A. (1991) Modernity and Self-identity. Stanford: Stanford University Press. 
Gilligan, P. \& Furness, S. (2005) 'The Role of Religion and Spirituality in Social Work Practice: Views and Experiences of Social Workers and Students', British Journal of Social Work Advance Access published on October 3, 2005; doi: doi:10.1093/bjsw/bch252

Graham, J. (2006) 'Localizing Spiritually based Social Work in North America: Strategies and Prospects', Keynote Address, First North American Conference on Spirituality and Social Work, Waterloo, Canada, 25-27 May 2006.

Gray, M. (2006) 'Viewing Spirituality in Social Work through the Lens of Contemporary Social Theory’, British Journal of Social Work Advance Access http://bjsw.oxfordjournals.org/cgi/reprint/bcl078?ijkey=Hz96QItBtN0o9Uz\&ke ytype=ref.

Gray, M. (2007) The not so Critical 'Critical Reflection'. Editorial, Australian Social Work, 60: (2), 131-135.

Gray, M., Coates, J. \& Hetherington, T. (2007) 'Hearing Indigenous Voices in Mainstream Social Work’, Families in Society, 88(1): 53-64.

Habermas, J. (1972) Knowledge and Human Interests. (tr. J. Shapiro) London: Heinemann.

Habermas, J. (1974) Theory and Practice. (tr. J. Viertal) London: Heinemann. 
Habermas, J (1984) Theory of Communicative Action. (vol. I) Boston: Beacon Press.

Habermas, J (1987) Theory of Communicative Action. (vol. II) Boston: Beacon Press.

Habermas, J. (1990) Moral Consciousness and Communicative Action. (tr. C. Lenhardt \& S. Nicholson) Cambridge, MASS: Massachusetts Institute of Technology Press.

Habermas, J. (2001) The Liberating Power of Symbols: Philosophical Essays. Cambridge: Polity Press.

Habermas, J. (2002) Religion and rationality. (Essay collection edited by Eduardo Mendietta). Cambridge: Polity Press.

Henery, N. (2003) 'The Reality of Visions: Contemporary Theories of Spirituality in Social Work’, British Journal of Social Work 33: 1105-1113.

Holloway, M. 'Spiritual Need and the Core Business of Social Work', British Journal of Social Work Advance Access published on March 20, 2006. doi:10.1093/bjsw/bcl014

Idel, M. (1988) Kabbalah: New Perspectives. New Haven, Conn: Yale University Press. 
Idel, M. \& McGinn, B. (eds). (1999) Mystical Union in Judaism, Christianity, and Islam: An Ecumenical Dialogue. New York: Continuum.

Janz, B. (2005) Pre-Christian Mystics and Influences on Mysticism. Accessed 20 September 2005. http://www.clas.ufl.edu/users/gthursby/mys/whoswho.htm

Khalidi, T. (2001) The Muslim Jesus: Sayings and Stories in Islamic Literature. Cambridge, MASS: Harvard University Press.

Kvarfordt, C. (2006) ‘Children’s Spirituality: Implications for Social Work’, paper presented at the First North American Conference on Spirituality and Social Work, Waterloo, Canada, 25-27 May 2006.

Lovat, T. (2004) 'Aristotelian Ethics and Habermasian Critical Theory: A Conjoined Force for Proportionism in Ethical Discourse and Roman Catholic Moral Theology', Australian E-Journal of Theology, 3 http://dlibrary.acu.edu.au/research/theology/ejournal/aejt_3/Lovat.htm

Lovat, T. (2006) 'Practical Mysticism as Authentic Religiousness: A Bonhoeffer Case Study', Australian E-Journal of Theology, 6. http://dlibrary.acu.edu.au/research/theology/ejournal/aejt_6/lovat.htm

Martin, G. (2005) Millenium Dawn: The Philosophy of Planetary Crisis and Human Liberation. London: GTM. 
Plato (1987) The Republic. (tr. D. Lee) Harmondsworth: Penguin.

Plato (1989) Protagoras. (tr. C. Taylor) Oxford: Clarendon Press.

Plotinus (2005) http://plato.stanford.edu/entries/plotinus (accessed 20 September, 2005).

Sheridan, M.J. (2003) 'The Spiritual Person’, in E.D. Hutchinson (ed). Dimensions of Human Behavior: Person and Environment ( $2^{\text {nd }}$ edition). Thousand Oaks, CA: Sage.

Webb, S. (2006). Social Work in Risk Society: Social and Political Perspectives. London: Palgrave Macmillan.

Wuthnow, R. (2002). Interview with Robert Wuthnow. Religion \& Ethics NewsWeekly April 26, 2002 Episode no. 534. Accessed 30 June 2007. http://www.pbs.org/wnet/religionandethics/week534/rwuthnow.html 